\title{
Eremita alter philosophus: pojmovanje askeze v poganski in krščanski filozofiji
}

\section{Nena Bobovnik* in Gina Derhard**}

Evherij Lyonski (ok. 380-ok. 449), galski cerkveni oče iz Lérinsa, v svoji Hvalnici puščave (De laude eremi) puščavo okliče za najprimernejše prizorišče filozofije:

Clari apud veteres saeculi huius viri, defatigati laboribus negotiorum suorum, in philosophiam se tamquam in domum suam recipiebant. Quanto pulchrius ad haec manifestissimae sapientiae studia divertunt magnificentiusque ad solitudinum libertatem et desertorum secreta secedunt, ut, philosophiae tantum vacantes, in illius eremi deambulacris tamquam in suis gymnasiis, exerceantur! (De laude 32)

Utrujeni od naporov in dela so se nekateri sloviti možje izmed starih umaknili v filozofijo, kakor da bi se vrnili v svoj stari dom. A koliko lepše in veličastneje se $\mathrm{k}$ študiju te najresničnejše modrosti obračajo tisti, ki se umaknejo v svobodo osame. V skrivnostni odmaknjenosti se lahko posvečajo le filozofiji in se urijo v njej med sprehodi po puščavi, ki postane njihovo vadbišče! ${ }^{1}$

* Oddelek za filozofijo na Filozofski fakulteti Univerze v Ljubljani, Aškerčeva 2, Ljubljana, nena.bobovnik@gmail.com.

** Centrum für Religionswissenschaftliche Studien, Universitätsstraße 9oa, Bochum, gina.derhard@rub.de.

1 Prevod Nena Bobovnik; skupaj s krajšo spremno študijo bo prevod v celoti objavljen v prihajajoči številki revije Keria: Studia Latina et Graeca 21.3. Kritična izdaja: Pricoco, Elogio del eremo: Introduzione, testo, traduzione e commento. Prevodi in izdaje v članku niso posebej označeni, bralec jih najde v končni bibliografiji, razen če je prevod delo avtoric. 
Čeravno svojo hvalnico posveča otoškemu samostanu in meniški skupnosti, ${ }^{2}$ v njej prvenstveno poveličuje puščavo. Enkomij naslavlja tako na dejansko pokrajino kot na koncept puščave - skozi svojo alegorizirajočo eksegezo oba vzpostavlja kot ideal. ${ }^{3}$ Članek bo v nadaljevanju pokazal na razlog za tako spontan prenos filozofije v roke puščavnikov, kot ga opisuje Evherij, in opozoril na puščavo kot novum, ki ga v pojmovanje in prakticiranje askeze vpelje krščanstvo.

\section{ASKEZA IN ÁSKESIS}

Abstraktni samostalnik áskesis izhaja iz grškega glagola askéo, kar pomeni »vadim, vežbam; bavim, ukvarjam se s čim«. To implicira nekoliko drugačen pomen od tega, kar pod besedo "askeza« razumemo danes. Za opis strogega odrekanja užitkom, zavračanja telesa in telesnih potreb, s katerimi je termin obarvalo krščanstvo, ${ }^{4}$ grščina sploh nima ustreznega izraza. V svojem prvotnem pomenu se je namreč áskesis nanašala na »vajo« kot atletski oziroma športni trening ali pa »ukvarjanje s čim« v smislu opravljanja določenega poklica. Toda termin je prav v tem oziru imel svoj pomen tudi znotraj klasične grške filozofije. Kot del tripartitnega kriterija za filozofijo - za življenje, ki teži $\mathrm{k}$ dobremu, so namreč potrebne phýsis (naravna predispozicija), máthesis (učenje) in áskesis (vaja) - ga najdemo že na samem začetku Aristotelove Evdemove etike. ${ }^{5}$

2 Okoli leta 400 ustanovljeni samostan na otoku Lerina, danes Saint Honorat, v otočju Lérins (Ligursko morje pri Cannesu), predstavlja zibelko zahodnega meništva, ki se zvesto zgleduje po prvotnem egiptovskem puščavništvu. Meniška skupnost ima skoraj neprekinjeno tradicijo vse do današnjega dne, ko na otoku živijo cistercijanski menihi. O otoškem samostanu obširneje Pricoco, L'isola dei santi: il cenobio di Lerino e le origini del monachesimo gallico.

3 Najznamenitejšo vzpostavitev je moč zaslediti že v Atanazijevi Vita Antonii, splošen pregled ponuja Harmless, Desert Christians: An Introduction to the Literature of Early Monasticism, predvsem 11-24.

4 Pod te asketske krščanske prakse se običajno uvrščajo predvsem post (ieunium), bedenje (vigiliae), borna obleka in bivališče ter neprenehna molitev (oratio continua).

5 EE 1.1214a, cf. Nikomahova etika 10.10.1179b2o. Na prav to opozarja tudi Dillon, "Rejecting the Body, Refining the Body: Some Remarks on the Development of Platonist Asceticism«, 86. 
Pierre Hadot, ki v svojih študijah ${ }^{6}$ prepričljivo ovrže pojmovanje antične filozofije kot strogo teoretske dejavnosti in pokaže, da je ta $\mathrm{v}$ večinski meri pomenila način življenja (manière de vivre), pri tem opozarja tudi na stoiško, kiniško, skeptiško in novoplatonsko filozofijo, v kateri ima áskesis pomen »duhovnih vaj«? Tudi te so implicirale zavzetje odklonilnega odnosa do telesa, prav tako pa tudi same »telesne vaje« poganski antiki niso bile neznane. Zdi se torej, da krščanstvo semantiko in etimologijo askeze zgolj spoji. Rečeno drugače, zgodnjekrščansko pojmovanje asketizma je bilo dedič poganskega v obeh ozirih: prvi krščanski asketi niti svojega pojmovanja niti prakse askeze niso ustvarjali ex nihilo. Na eni strani je namreč, kot je pokazal Hadot, áskesis v smislu duhovnih vaj predstavljala temelje velikega dela poganske filozofije, ki jih je meništvo zgolj prevzelo. Na drugi strani pa je, čeprav zanj niso imeli izraza, tudi telesno prakticiranje askeze obstajalo že veliko pred pojavom krščanskega asketizma. ${ }^{8}$ To zadnje je ključno - spričo tega krščanstvu invencije asketskih telesnih praks ne moremo pripisovati stricto sensu. V nadaljevanju bo članek pokazal na inherentno soodvisnost askeze in áskesis, ki pravzaprav le redko obstajata vsaka zase. Prek poganske filozofske utemeljitve asketizma bo skušal izpostaviti resnično zarezo, ki jo v asketski diskurz in prakso vpelje krščanstvo. Najprej pa bo iskal poganske izvore askeze, ki jih je krščanstvo privzelo in jih obrusilo do najverjetneje najvišje oblike asketizma - meništva.

O natančnejši časovni določitvi njegovega nastanka se sicer še vedno razpravlja. Hermann Weingarten (1834-1892), protestantski cerkveni zgodovinar, je v prispevku z naslovom Der Ursprung des Mönchtums im nachconstantinischen Zeitalter, ki ga je objavil v prvi številki Zeitschrift für Kirchengeschichte, ${ }^{9}$ prvi zavzel kritiško pozicijo in se obregnil ob resnični obstoj Pavla iz Teb - po izročilu prvega

6 Tu sta v središču predvsem Hadot, Philosophy as a Way of Life: Spiritual Exercises from Socrates to Foucault in Kaj je antična filozofija? - v izvirniku Exercices spirituels et philosophie antique in Qu'est-ce que la philosophie antique?

7 Hadot sprva med vprašanjema, koliko je bilo »krščanske askeze«že pri antičnih filozofih ter koliko so antični filozofi s svojo áskesis kot duhovno vajo vplivali na krščanske askete, ne vidi pomembnejše soodvisnosti; prim. Hadot, Philosophy as a Way of Life, 128. Vendar to stališče pozneje omili - pod »duhovne vaje« (exercices spirituels) tako šteje bodisi »telesne«, »diskurzivne« ali »intuitivne» vaje. Ibid, 17 .

8 Kljub letnici integralno delo še zmeraj ostaja Swaine, The Hellenic Origins of Christian Asceticism.

9 Weingarten, »Der Ursprung des Mönchtums im nachconstantinischen Zeitalter«, $1-35$. 
puščavnika. ${ }^{10}$ Prav tako naj bi Hilarion, učenec Pavlovega učenca Antona Velikega, ${ }^{11}$ obstajal le v domišljiji svojih hagiografov. ${ }^{12}$ Weingarten tako začetek pravega meništva postavlja šele $\mathrm{v}$ drugo polovico četrtega stoletja - v čas po smrti Konstantina Velikega. ${ }^{13}$ Ta visokoleteča teza sicer že dolgo velja za ovrženo, vendar točna časovna ločnica še danes ostaja nedoločena: ${ }^{14} \mathrm{v}$ študiji se ustavljava pri konvencionalni, čeprav poenostavljajoči določitvi Antona kot pionirja puščavništva in Pahomija kot očeta samostanskega meništva. $^{15}$

\section{TELO »NAJ SLUŽI IN JE VLADANO«: PLATONIZEM IN ZAVRAČANJE TELESNOSTI}

Endre von Ivánka, avtor monografije o krščanskem platonizmu, ki še zmeraj velja za temeljno delo, bistveno zadrego patristične teologije vidi v njeni »rabi platonizma kot oblike filozofskega izraza«. ${ }^{16}$ André-Jean Festugière je v svojih ugotovitvah, da patri-

10 Poglavitni vzrok takšne percepcije je Hieronim, avtor hagiografije Vita Pauli primi eremitae, v kateri za prvega meniha postavi Pavla, ne Antona.

11 O katerem Atanazij napiše slovito Vita Antonii. Kot pa opozarja Rubenson, je Atanazijeva hagiografija prej posledica kot vzrok Antonove slave, prim. Rubenson, "Christian Asceticism and the Emergence of the Monastic Tradition«, 50.

12 Ibid. Tudi avtor Vita Hilarionis je Hieronim.

13 Weingarten ni verjel niti v zgodovinskost Antona Velikega, Atanazijevo Vita Antonii je prišteval med spuria.

14 Cf. Harmless, Desert Christians 3-25, Judge, »The Earliest Use of Monachos for 'Monk'«, 72-89; da se »big bang theory« meništva zmotno postavlja le v egiptovski prostor in da so podobne, če ne celo bolj razgibane prakse obstajale tudi na območju Sirije in Palestine, opozarja Goehring, "The Origins of Monasticism«, o »svetih možeh", ki so imeli na območju sirskih puščav še večji pomen, piše Brown, »The Rise and Function of the Holy Man in Late Antiquity«, 80-101.

15 Anton se ok. leta 270 napoti v puščavo, Pahomij pa ok. 320 ustanovi prvo meniško skupnost (koinonía), vendar pripisovanje pionirske vloge tako Pahomiju kot Antonu temeljito problematizira Goehring, »Withdrawing from the Desert: Pachomius and the Development of Village Monasticism in Upper Egypt«, 91. O tem, da Anton, ki velja za očeta meništva, zagotovo ni bil prvi menih in da so nekateri asketi živeli puščavniško že pred njim, poroča že Atanazij sam (VA 3): »V tistem času v Egiptu še ni bilo samotišč in noben menih ni vedel ničesar o veliki puščavi. Kdor je hotel biti pozoren nase, je začel z askezo v samoti, ne daleč stran od svoje vasi.« Slovenski prevod Vita Antonii je objavil Movrin, Izviri meništva, 9-105.

16 Ivánka, Plato Christianus: Übernahme und Umgestaltung des Platonismus durch die Väter, 19. 
stična mistika ni nič več in nič manj kot platonsko filozofiranje, še nazornejši. ${ }^{17}$ Tudi kar zadeva asketizem, pri Platonu najdemo številna mesta, iz katerih je izhajalo tudi krščanstvo, hkrati pa se je sámo porodilo v svetu, ki je bil močno zaznamovan s platonsko mislijo.

Asketski diskurz se znotraj platonizma pojavi predvsem v paradigmi dualističnega pojmovanja človeka, pri katerem je, v grobem, duša istovetna s človeškim bistvom, telo pa njena ovira na poti k višji duhovni ravni. V Fajdonu je to večkrat izpostavljeno - Sokrat pravi, da »narava telesu ukazuje, naj služi in je vladano,

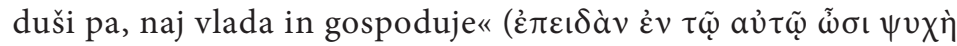

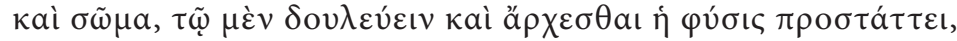

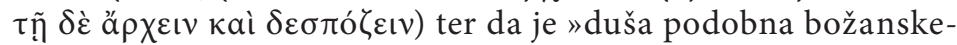

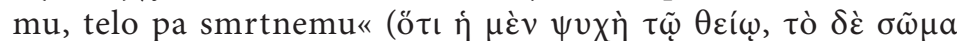
$\tau \tilde{\omega} \theta \nu \eta \tau \tilde{\omega}) .{ }^{18}$ Še ostreje se antitetično trenje med dušo in telesom zastavi v dialogu Gorgija, kjer se Platon navezuje na nauk o sóma-séma, torej na nauk o dojemanju telesa kot groba duše, ki naj bi ga povzel od »nekega modreca«, domnevno pitagorejca. ${ }^{19}$ V Alkibiadu govori o telesu kot o nečem, kar človeku le pripada, ni pa človek sam, ${ }^{20}$ v Fajdonu pa o duši, ki je »zvezana v telesu“ $(\delta\llcorner\alpha \delta \varepsilon \delta \varepsilon \mu \varepsilon \dot{\varepsilon} \nu \nu)$ in nanj "prilepljena« ( $\pi \rho \circ \sigma \kappa \varepsilon \kappa o \lambda \lambda \eta \mu \varepsilon \dot{\varepsilon} \nu \nu)$ :

Festugière, Contemplation et vie contemplative selon Platon, 5 .

Fjdn. 8oa.

Cf. Krtl. 40ob, Drž. 9.586a in Fjdn. 61e-62c, kjer je namesto samostalnika séma uporabljen izraz phrourá, ki lahko pomeni tako »ječo« kot »stražo«; o tej distinkciji so v poznejši recepciji obširno razglabljali, če naštejemo najvidnejše: Damaskij, In Phaedrum 1.2; Ciceron - kot v op. 24, in Plotin, ki se v Eneadah 4.8.1, kot bo nakazano v nadaljevanju, neizpodbitno izreče za telo kot ječo duše, omenja pa tudi, da je »Platon vso telesno naravo označil za nekaj slabšega (sc. kot »oviro za telo»)«.

Alk. I.131b: "Če nekdo neguje svoje telo - ali ne neguje nečesa, kar mu pripada, in

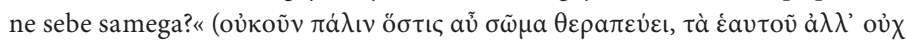

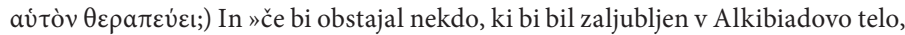

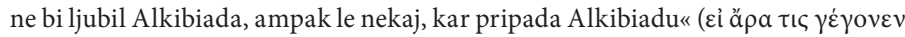

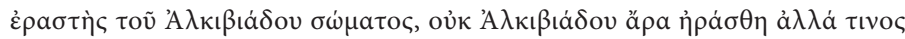

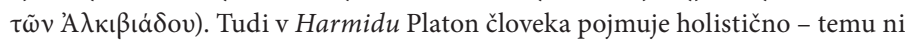
moč pozdraviti telesa, če se ne pozdravi tudi njegova duša. V Kritonu (403b) in Gorgiju (524d) pa se med eshatološkimi temami pojavi pojmovanje telesa, kot oblačila duše, ki ga ta ob smrti sleče. Naposled pa tudi ob koncu dialoga Timaj (9oa), kjer govori o treh oblikah duš, Platon omenja najvišjo obliko duše, ki »biva na vrhu telesa in nas zaradi sorodnosti $z$ nebom dviga z zemlje, saj nismo zemeljska, temveč nebeška rastlina«. 


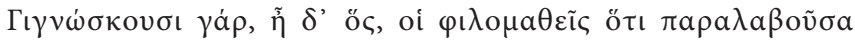

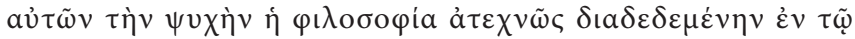

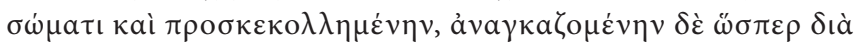

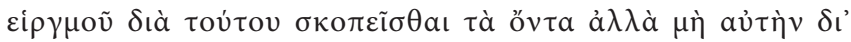

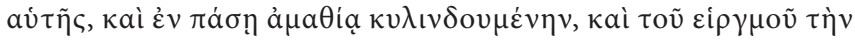

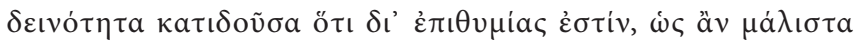

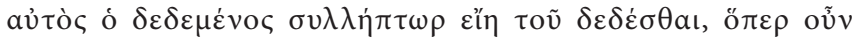

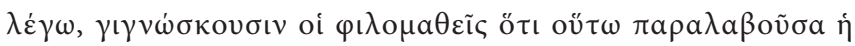

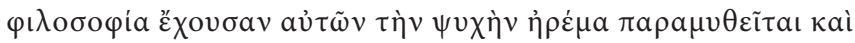

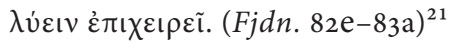

Radovedni ljudje vedo, kako je bila njihova duša, ko jo je prevzela filozofija, naravnost zvezana v telesu in nanj prilepljena, prisiljena opazovati bivajoče resničnosti prek telesa kot iz ječe, ne sama prek sebe; valjala se je v popolni nevednosti. Filozofija pa je uvidela, da je strašnost ječe posredovana s poželenjem, tako da ta, ki je vklenjen, celo najbolj pripomore k svoji vklenjenosti. Tako torej - kot sem dejal, radovedni to že vedo - filozofija prevzame njihovo dušo v takšnem stanju, mirno ji prigovarja in jo skuša odrešiti.

Kot pravi Sokrat v Teajtetu, je pravemu filozofu za čutne reči, ki jih ima neposredno pred seboj, in svoje telo tako malo mar, da mu »ni skrito le to, kaj dela, temveč celo to, ali je človek ali kakšno drugo

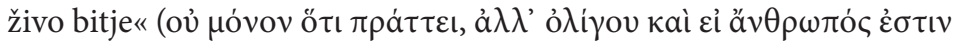
$\eta ̋$ ra v Fajdonu - filozofijo poistoveti z »vajo v smrti«:

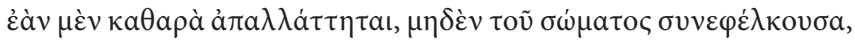

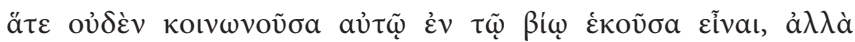

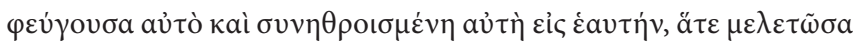

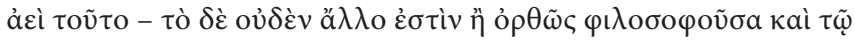

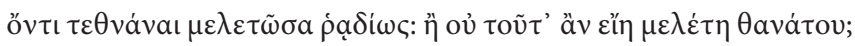
(Fjdn. 8oe-81a)

Če se duša (od telesa) loči čista in ne vlači s seboj nič telesnega, ker se v življenju ni v ničemer rada družila s telesom, temveč je pred njim bežala in se je zbirala sama vase, saj se je vedno vadila v tem - kar z drugimi besedami pomeni, da je pravilno filozofirala in se resnično vadila $\mathrm{v}$ tem, kako se umre $\mathrm{z}$ lahkoto ... - Ali ni to vaja $\mathrm{v}$ smrti?

21 Cf. ibid. 83d-e.

22 Tjt. 174b. 
Filozofija v tem oziru postane vaja v »begu pred telesom«, telo pa predstavlja oviro za dušo na njeni poti k čistemu vedenju. ${ }^{23}$ Platonovi napotki k temu, kako naj se s to oviro spopademo, se $\mathrm{z}$ malo hiperboličnosti berejo kot asketski manifest:

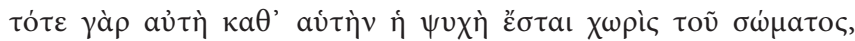

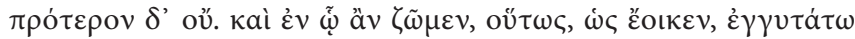

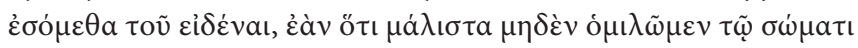

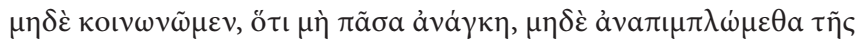

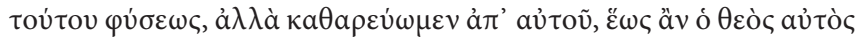

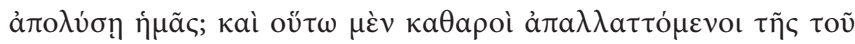

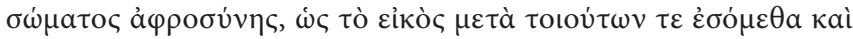

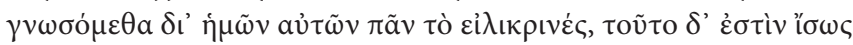

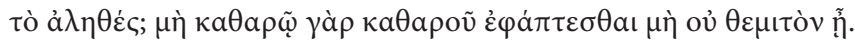
(Fjdn. 67a-b)

Dokler živimo - vsaj videti je tako - pridemo védenju najbližje tako, da se čim bolj izogibamo vsakemu druženju in občestvu s telesom, razen če to ni povsem nujno, in da se ne napolnjujemo $\mathrm{z}$ njegovo naravo, temveč se ga očiščujemo, dokler nas ne odreši sam bog. ${ }^{24}$ Tako bomo verjetno bivali v družbi takšnih čisti, osvobojeni nera-

Cf. Klemen Alexandrijski, Stromata 5.11, kjer aludira prav na ta Platonov odlomek; prav tako tudi Evagrij Pontski v Praktiku 52: »Telo lahko od duše loči le Tisti, ki ju je zvezal, dušo od telesa pa lahko loči tudi vsakdo, ki hrepeni po kreposti. Odmaknjenost od sveta so namreč naši očetje imenovali 'vaja v smrti'

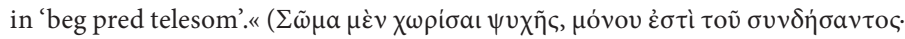

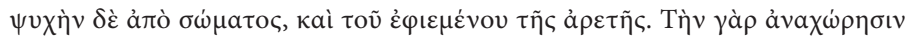

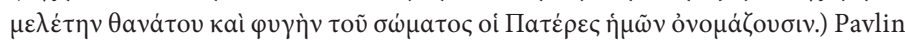
iz Nole pa v Ep. 45.4 govori o začetku meniškega življenja kot o smrti-za-svet (mortuus huic saeculo).

Odklonilen odnos do telesa je v navedenih odlomkih jasno izpostavljen, vendar ga Platon nikoli ne privede do skrajne točke, ki bi zagovarjala samomor. Ta je namreč v nasprotju $\mathrm{z}$ božjimi zakoni (cf. Fjdn. 62b). To pojmovanje in utemeljevanje moralne napačnosti samomora sicer Ciceron v Cato Maior de senectute 20.73 pripisuje že Pitagori: „Tudi Pitagora prepoveduje odstopiti od obrambe in ohranjanja življenja brez ukazov vrhovnega poveljnika, to je Boga« (vetatque Pythagoras iniussu imperatoris, id est dei, de praesidio et statione vitae decedere). Napotiti pa velja tudi na dva zanimiva primera recepcije dotičnega problema telesa kot ječe in razmišljanj o samomoru pri patrističnih avtorjih: Teodoret, Graecarum Affectionum Curatio 12.53.1, in Klemen Aleksandrijski, Stromata 4.4.17. Cf. interpretacijo antropogonije in nedopustnosti samomora, ki ju v svojem komentarju k Fajdonu utemeljuje Olimpiodor; Božič, »Dionizova smrt in etični dualizem: nekaj misli o Olimpiodorjevi antropogoniji in neoplatonističnih opisih manihejskega kozmosa«, 31-44. 
zumnosti telesa, in bomo prek samih sebe spoznali vse, kar je čisto. To pa je bržkone Resničnost. Nikakor namreč ni dovoljeno, da bi se nečisti dotikal čistega.

Skrb za dušo dobi v Platonovi filozofiji absolutno prednost pred skrbjo za telo, ki je samo po sebi drugotnega pomena. Takšno razumevanje tvori pogled na človekovo bivanje, ki se zdi zelo blizu krščanski percepciji večvrednosti življenja duše nad življenjem mesa.

$\mathrm{Na}$ reverzu asketizma, ki je implicitno prisoten v platonizmu, pa, na prvi pogled nekonsistentno, leži prav skrb za telo. Vendar ne skrb kot nega in osredotočenost na telo, temveč skrb v smislu »discipline«, »samoobvladovanja« in »vzdržnosti«, ki jo ponazarja grški termin enkráteia. Temu se pridružujeta tudi "premišljenost« in "preudarnost«, ki ju zajema grški pojem sophrosýne. O njegovem pomenu beremo v četrti knjigi Države, da je:

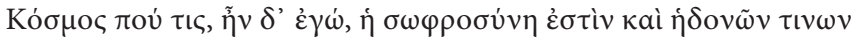

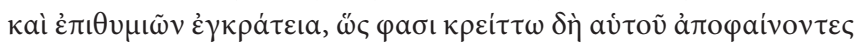

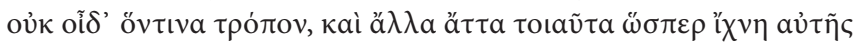
$\lambda \dot{\varepsilon} \gamma \varepsilon \tau a$. $(\text { Drž. } 4.430 \mathrm{e})^{25}$

/.../ nekakšen red in obvladovanje nekih užitkov in poželenj, kot pravijo ljudje, ko uporabljajo, ne vem sicer v kakšnem smislu, izraz 'močnejši od samega sebe'; in tudi o drugih podobnih rečeh govorijo kot o sledeh premišljenosti.

Načela poznejše krščanske askeze so videti kot neposreden odmev navedenih odlomkov. Šele z vztrajno samo-disciplino, postom, nočnim bedenjem in drugimi raznovrstnimi telesnimi "vajami« postane za krščanskega asketa združitev z Bogom sploh možna. Tako v platonskem kot krščanskem pojmovanju askeze je torej moč zaznati temeljno dihotomijo med zavračanjem telesa na eni strani in osredotočanjem nanj na drugi. Ta navidezna nekonsistentnost korenini $\mathrm{v}$ prepričanju, da ravno skozi umerjanje telesa $\mathrm{z}$ dušo, ki ga dosegamo preko telesne askeze, lahko dosežemo življenje na višji duhovni ravni. Povedano drugače, hkrati s posvetitvijo duhovnosti se je ne-

25 Tudi dialog Harmid, ki se sicer konča v aporiji, je v celoti posvečen razglabljanju o pravem pomenu tega termina; cf. tudi Krtl. 411e. Znotraj krščanstva pa sophrosýne dobi nekoliko drugačen pomen: krščanski avtorji jo razumejo kot »duševno čistost«, pri Evagriju Pontskem pa že označuje celo »neodvisnost od spolnega poželenja in ujetosti v erotične fantazije, torej krepost, nasprotno 'nečistosti' «. Evagrij Pontski, Spisi in pisma, 48 op. 44. 
izogibno posvetiti tudi telesnosti. Slednja predstavlja, če ne drugega, oviro na poti h globljemu dušnemu življenju, za katero je treba, preden se bi je sploh lahko »rešili«, najprej (po)skrbeti. ${ }^{26}$ Skrbi za dušo je predpostavljena skrb za telo, v katerega je duša ujeta.

Še ena strukturna podobnost se kaže v notranjem imperativu posredovanja duhovnega uvida, ki ga je doživel bodisi platonski filozof bodisi krščanski puščavnik. Ko se Anton Veliki že umakne $\mathrm{v} »$ notranjo goro in se posveča le še strogi askezi, tam ne ostane povsem sam zase, ločen od sveta. Še zmeraj je v vlogi duhovnega pastirja in četudi tega ne jemlje za svoje primarno poslanstvo, ljudi na njihovo prošnjo tudi večkrat nagovarja. S svojim bivanjem v puščavi navdihne množice, da sledijo njegovemu zgledu ali se le oplajajo ob njegovem načinu življenja. Čeprav je primarni kriterij puščavništva odmik od sveta - osama, puščavniki nikoli niso bili prav zares sami. ${ }^{27}$ Njihova svetost je pritegnila mnoge gorečneže, ki so se organizirali v meniške skupnosti ali pa so k njim prihajali le kot romarji. ${ }^{28}$ Puščavnik torej nolens volens predaja svoje uvide ljudstvu, kar spominja na Platonov prototip filozofa iz prispodobe o votlini. Tudi on se je po tem, ko uzre najvišje Dobro, prisiljen vrniti v svet senc med ljudi. Le on je namreč vreden voditi državo in »zahteve, da skrbi za druge ljudi in jih varuje«, ki jih filozofu nalaga ljudstvo, so povsem »pravične«. ${ }^{29}$

\section{ZAOSTROVANJE PLATONSKEGA ASKETIZMA}

Novoplatonsko branje Platona dualizem med dušo in telesom še radikalizira, kot je razvidno že iz Porfirijevega (ok. 234-305) prvega stavka v Vita Plotini: »Videti je bilo, kakor da se Plotin, filozof naše-

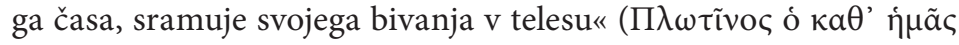

Cf. Graiver, Asceticism of the Mind: Forms of Attention and Self-Transformation in Late Antique Monasticism, 2018.

27 Cf. Ware, "The Way of the Ascetics: Negative or Affirmative? « 5-6. Idealizirajočim hagiografijam namreč ne gre verjeti dobesedno. V njih je denimo, kot piše Hieronim v svoji Vita Pauli, neki menih vse svoje življenje preživel ob petih suhih figah na dan ( $V P$ 6). V resnici razmere niso bile tako drastične niti pri puščavnikih, ki so živeli najstrožje. Hrano so dobivali tudi od prebivalcev bližnjih mest in romarjev, ki so jih obiskovali. O dojemanju samote pri puščavskih svetih starcih piše Gould, The Desert Fathers on Monastic Community, 139-66. Cf. Frank, The Memory of the Eyes: Pilgrims to Living Saints in Christian Late Antiquity. Drž. $7.520 a$. 


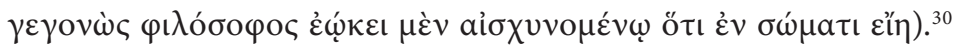
Zaostri se tudi pojmovanje telesa kot snovi, v katero je ujeta duša. Sam Plotin (ok. 204-270) v traktatu O sestopu duše v telesa ujetost duše v telo razume celo kot kazen, ${ }^{31}$ njegov učenec Porfirij pa razpravi o telesni vzdržnosti posveti štiri knjige De abstinentia. Delo je primarno uperjeno zoper uživanje mesa in zagovarja vegetarijanstvo, ${ }^{32}$ ki ga Porfirij prevzema iz pitagorejske tradicije, vendar se tudi prehranske navade utemeljujejo na podlagi večvrednosti duše nad vrednostjo telesa. V prvi knjigi Porfirij nagovarja svojega prijatelja, dobro situiranega Rimljana Kastricija Rufa, naj se mu pridruži v povsem novi disciplini - olimpijskih igrah duše:

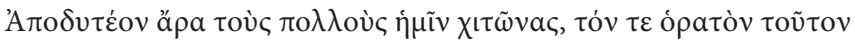

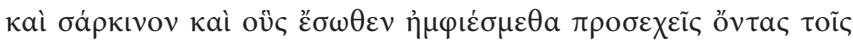

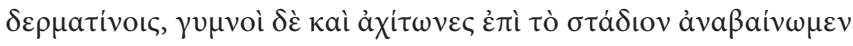

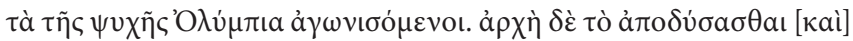

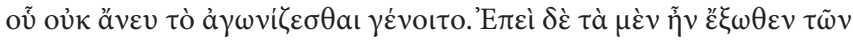

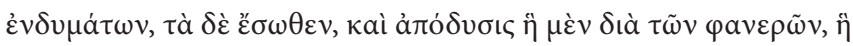

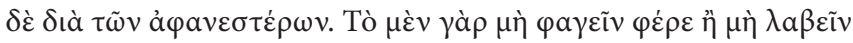

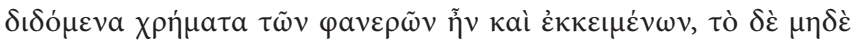

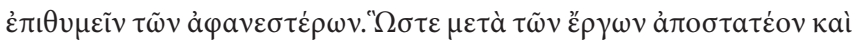

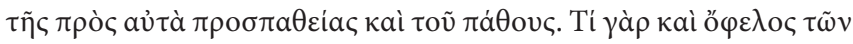

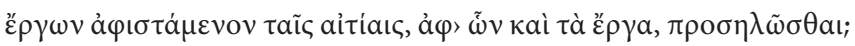
(De abstinentia 1.31.12-1.32)

Sleči moramo vso množico oblačil, tako ta, ki so vidna in so iz mesa, kot ona, v katera smo odeti v svoji notranjosti, in ki so najbližje koži. Goli, brez oblek, stopímo na olimpijski stadion duše, da bi se borili na njem. Še preden sploh lahko začnemo, se moramo namreč sleči. In ker del oblačil nosimo na sebi, drugi del pa v sebi, si moramo sneti ta, ki so vidna, kot tudi tista, ki so bolj skrita. Da ne segamo po hrani in grabimo po rečeh, ki so nam dane, spada med bolj očitne

31 Plotin govori o dveh "napakah« (hamartía) duše: prva je, da ta sploh izgubi krila in se utelesi (cf. Fjdr. 248c), druga pa, da postaja zla, ko je enkrat že v telesu, pri čemer je kazen za prvo napako "prav to, kar duša utrpi ob sestopu«, za drugo pa, »da se na hitro pogrezne v druga telesa v skladu s sodbo, izrečeno glede na to, kar si je zaslužila«.

32 Nemara najboljši uvod v odnos do hrane v antiki in njegovo recepcijo v krščanstvu prinaša Bynum, Holy Feast and Holy Fast, predvsem na straneh 31-40 ter 189-219, kjer avtorica odpira vprašanje posta in odnosa žensk do hrane v pozni antiki, ki je morda mejil na anoreksijo. 
stvari, da pa si ne želimo reči, spada med bolj skrite. Tako se moramo poleg dejanj samih obraniti tudi lastnih želja in strasti do teh dejanj. Kaj nam navsezadnje pomaga, če se vzdržimo samih dejanj, a hkrati hrepenimo po razlogih, iz katerih ta dejanja izhajajo ${ }^{33}$

Porfirij filozofijo opisuje kot disciplino, ki ima svoje lastne olimpijske igre. Na njih se bori človekova duša, ki pa pripravljalni trening potrebuje ravno toliko, kot ga potrebuj telo, ki namerava tekmovati. ${ }^{34}$ Sredstva so podobna, četudi je cilj povsem drugačen. Pri zadnjem gre za športne dosežke, pri prvem za združitev z Enim. ${ }^{35}$

Omeniti velja tudi Porfirijevo pismo Ad Marcellam iz leta 30o, ki ga je namenil svoji ženi. Napisal naj bi ga kot literarno apologijo za svoj zakonski stan, saj je sam posvečenost filozofiji vrednotil veliko višje kot posvečenost ženski, četudi bi šlo za filozofovo življenjsko sopotnico. ${ }^{36} \mathrm{~V}$ njem poveličuje filozofijo kot edino, ki ima moč, da človeka reši navezanosti na telo in ga osvobodi telesnih spon.

Še pred Plotinovo recepcijo platonske filozofije pa se nanjo neposredno nanaša tudi filozof, za katerega ne vemo, »ali je bil Platonov sledilec sam, ali je sam Platon sledil njemu« (Plato Philonem sequitur, aut Platonem Philo), kot Filona Aleksandrijskega (20 pr. Kr.-50 po Kr.) v De viris illustribus opiše Hieronim. ${ }^{37}$ Gre za v judovskem izročilu zakoreninjenega ${ }^{38}$ filozofa, ki ga Harry Austryn Wolfson v svoji integralni študiji postavi za utemeljitelja zahodne filozofije, iz katere se pozneje razvije filozofija spinozističnega kova. ${ }^{39}$

V Filonovem spisu De vita contemplativa naletimo na opis proto-meniške skupnosti asketov, ki je živela v bližini Aleksandrije. Šlo je za skupino ljudi, ki so se odmaknili od mestnega

Prevod Nena Bobovnik.

Cf. 1 Kor 9,24-27: »Mar ne veste, da tisti, ki tečejo na tekališču, res vsi tečejo, da pa le eden dobi nagrado? Tako tecite, da jo boste dosegli. Vsak tekmovalec pa se vsemu odreče, ôni, da prejmejo venec, ki ovene, mi pa nevenljivega. Zato jaz ne tečem kar na slepo, ne bojujem se, kakor bi mahal po zraku. Nasprotno, trdo ravnam s svojim telesom in ga usužnjujem, da ne bi bil sam zavržen, ko oznanjam drugim.«

Finn, Asceticism in the Graeco-Roman World, 9.

Cf. Whittaker, »The Purpose of Porphyry's Letter to Marcella«, 150-68.

Vir. ill. 11.

Krščanski asketizem ima svoje korenine tudi v judovski tradiciji, česar se članek ne dotika. Kot pomemben zgled se kažejo že eseni; tudi post je del judovskega dojemanja vere, za obširnejšo proučitev asketizma v judovstvu glej Finn, Asceticism in the Graeco-Roman World, 34-131.

Wolfson, Philo: Foundations of Religious Philosophy in Judaism, Christianity, and Islam. 
vrveža, zavračali posvetno življenje in telesnost ter se posvečali askezi. Pripadniki te skupnosti, ki jih Filon imenuje therapeutae, so najverjetneje najboljši približek krščanskim puščavskim menihom, ki so se pojavili slaba tri stoletja pozneje. Še za časa življenja so bili tako "prebivalci neba kakor tudi prebivalci ne-

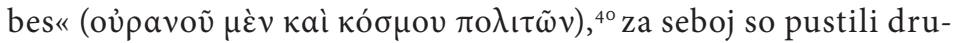
žino in prijatelje, ${ }^{41}$ mesa niso uživali in so bili na sploh vzdržni pri hrani. ${ }^{42}$ Idealizirali so pomen pojma enkráteia, v skladu s katerim so tudi živeli. ${ }^{43}$ Odnos duša-telo se pri Filonu jasno navezuje na platonsko tradicijo - duša je ujetnica, ki si prizadeva za pobeg iz svoje ujetosti v snov. V delu De gigantibus Filon to pomenljivo opiše s prispodobo o dušah, ki naj bi z utelešenjem padle v vrtinčast tok hudournika. Večinoma se potopijo vanj in živijo pod gladino, duši filozofa pa ni potrebno veliko časa, da splava na površje in se tako toliko hitreje vrne v svoje pravo nebeško domovanje. ${ }^{44}$

\section{KINIŠKA IN STOIŠKA ÁSKESIS}

Kot rečeno, se je asketska oziroma celo proto-meniška naravnanost pojavljala že v poganski filozofiji. Soodvisnost telesne askeze in njenih filozofskih temeljev se je kazala predvsem v odklonilnem odnosu do telesa; pri čemer je ta izhajal iz filozofskih stališč, izražal pa se je v zavračanju telesnih potreb. V članku pa se še nisva obširneje dotaknili razlage antične áskesis, pojmovane kot »duhovne vaje« to niti ni potrebno, saj so k temu zelo veliko doprinesle že omenjene študije Pierra Hadota. Ustavljava se le pri dveh ključnih zgledih.

Praksa duhovnih vaj, ki jo najdemo že pri poganskih filozofih, se $\mathrm{z}$ duhovnostjo krščanskih asketov in menihov najjasneje stika $\mathrm{v}$ stoiški filozofiji. Eden izmed njenih poglavitnih pojmov, ki jih prevzame tudi krščansko meništvo, je namreč prosoché - "pozornost «. ${ }^{45}$ $\mathrm{S}$ tem terminom se v stoicizmu označujejo duhovne vaje, ki zaje-

Cont. 90. O »državljanstvu« (municipatus) na zemlji pa tudi v nebesih cf. Hieronim, Ep. 58.2, ter tudi Evherij, De laude 31; 43.

Cont. 18-21.

Cont. 73-74.

Cont. 34 .

Gig. 12-16.

Cf. Hadot, Kaj je antična filozofija? 252-57. Vsekakor pa to ni edini koncept, skupen stoiškim in meniški duhovnim vajam, vsaj omeniti je potrebno tudi pojem apátheia (»brezstrastnost«, »nedovzetnost za občutja«). 
majo introspekcijo, opazovanje in osredotočenost človeka samega nase - najznačilnejši predstavnik je Mark Avrelij. ${ }^{46}$ Prav takšne »vaje« so gojili tudi prvi menihi. Atanazij Antonovo spreobrnjenje opiše takole: "sam pa se je poslej namesto hiši posvečal askezi«

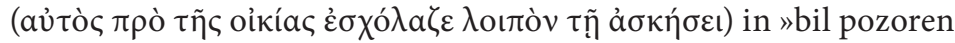

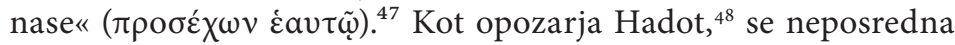
povezava stoiške prosoché $\mathrm{z}$ meniško še jasneje vidi v Antonovem napotku učencem, naj vsi opazujejo in si zapisujejo (sic!) »dejanja

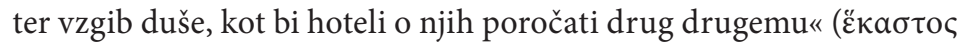

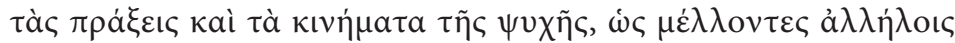

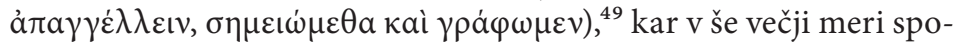
minja na prakso stoikov. Prvi asketi v puščavi so torej prav tako kot filozofi na prestolu udejanjali stoiški ideal pozornosti - tako Anton Veliki kot Mark Avrelij sta se skrbno zazirala v svojo notranjost, ta praksa pa je ostala prisotna tudi v vsakdanjiku vseh poznejših meniških rodov.

Drugi zgled je morda prima facie še očitnejši. Prvi krščanski asketi so, kot smo videli, zavzemali podobna asketska stališča kot Sokrat. Za njim pa je askezo do povsem svojevrstne skrajnosti privedel »Sokrat, ki se mu je zmešalo «5 $^{50}$ kot so govorili za Diogena iz Sinope, slavnega kinika, ki je živel v sodu in zavračal vse oblike človeškega življenja, ki človeku niso nujno potrebne. Za doseganje srečnosti in vrline so Diogen in kiniška šola posegali po »vaji«(áskesis) in "naporu« (pónos). Njihova filozofija je temeljila na življenjski praksi, skozi katero so krepili telo in duha, da sta bila zmožna prenašati vse vrste naporov. Filozofijo so torej v prvi vrsti

Cf. Tà eis heautón 2.7-11, 3.11, 6.13. Temeljno študijo predstavlja Hadot, La Citadelle intérieure: Introduction aux Pensées de Marc Aurèle. VA 3, cf. VA 91.

48 Hadot, Philosophy as a Way of Life, 131. Hadot se je glede »skrbi zase« spustil v polemiko z Michelom Foucaultom, ki o tem piše v tretjem delu svoje Zgodovine seksualnosti. Tam tudi sam razpravlja o Antonovih napotkih k pisanju »duhovnih zvezkov«. Ibid, 209. VA 55. Omenjeno presečišče stoicizma in puščavniške duhovnosti, na katerega naletimo v Antonu Velikem, lepo ponazarja tudi dejstvo, da je ravno PsevdoAnton v zbirki Filokalija postavljeno na prvo mesto. Besedilo, pripisano Antonu je pravzaprav stoiški traktat, ki ga uredniki Filokalije razumejo kot povsem krščansko besedilo in ga uvrstijo na sam začetek antologije pravoslavne meniške duhovnosti. Prevod v slovenščino bo pri založbi KuD Logos izšel še letos v prvem zvezku Filokalije. Diogen Laertski, Življenja in misli znamenitih filozofov 6.54 . 
razumeli kot način življenja, čeravno je bila metafizična podlaga te prakse izgubljena nekje s prevodom filozofije kot intelektualne, diskurzivne dejavnosti v živeto filozofiranje..1

\section{RAZMAH ANAHOREZE}

Kljub postopnemu zaostrovanju se asketizem, ki izhaja iz platonske misli, ne izteče v radikalno pretrganje družbenih vezi. Poganski "božji možje« (theîos anēr), ${ }^{52}$ kot so se nam ohranili v opisih svojih biografov, so stkali vzorec filozofsko-svetniškega življenja, ki so ga krščanski sveti možje sicer prevzemali, a med pogoje za živeto svetost uvrstili tudi fizično osamitev. ${ }^{53}$

Med najpomembnejše poganske zglede se uvrščajo Porfirijevi Vita Pythagorae in De vita Plotini, Filostratovo Vita Apolonii in Evnapijeve Vitae sophistarum. Podobnost med omenjenimi filozofskimi modreci, opevanimi v literariziranih življenjepisih, in krščanskimi svetimi možmi, kot jih opisujejo hagiografije, je mestoma zelo nazorna. Ideal poganskega in krščanskega svetniškega moža ima skupno, domala arhetipsko podobo: za oba je značilna vloga duhovnega vodje, okrog katerega se zbirajo učenci, njuna svetost oziroma božanskost se izraža prek številnih čudežev in nadzemskih sposobnosti, oba se odmikata od družbe, zavračata telesnost in promovirata posebne prehranske navade. ${ }^{54}$ Ena izmed ključnih razlik pa je radikalen in načrtni umik v osamo, ki se zgodi s krščanskim asketizmom. Fizična osamitev postane temeljni kriterij askeze. Takšno izolacijo, kot zapiše Hannah Hunt, lahko razumemo kot "pokristjaVsaj opozoriti pa je potrebno tudi na skepticizem, ki že skozi lik svojega začetnika Pirona izkazuje podobno nagnjenost k askezi. Hadot, Kaj je je antična filozofija? 124-27.

52 Temeljna študija je še zmeraj Bieler, Theios aner: Das Bild des »göttlichen Menschen« in Spätantike und Frühchristentum. Že v poimenovanju pa se kaže razločevanje med krščanskim in poganskim svetniškim možem, za prvega se namreč redko najde opis »božji človek «, spričo krščanske ponižnosti, ki si nikoli ne domišlja, da je človek enak Bogu, krščanski avtorji raje uporabljajo poimenovanje »človek Boga" (ánthrōpos Theoû).

53 Za temeljno obravnavo v slovenščini glej Movrin, »Izviri onkraj izvirov: odnos med pogansko in krščansko biografijo v pozni antiki«, 241-414.

54 Cf. Finn, Asceticism in the Graeco-Roman World, 10. Vse omenjeno pravzaprav najdemo že pri predsokratskem filozofu Empedoklu. Cf. Kingsley, Ancient Philosophy, Mystery, and Magic: Empedocles and Pythagorean Tradition. 
njenje helenističnih asketskih tradicij «. ${ }^{55}$ Poganski asket se sicer ni menil za družbeni status, odrekal se je družbi, vendar je ostajal vpet vanjo. Krščanski asketi pa so načelno zapuščali mesta ${ }^{56}$ in se zatekali v puščavsko samoto - "puščava je postala mesto menihov« (кaì ฑं

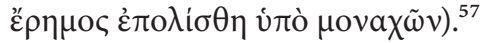

$\mathrm{V}$ začetkih krščanskega asketizma smo tako priča rojstvu anahoreze (anachóresis) - odmiku, umiku v samoto, ${ }^{58}$ od koder anahoretom (tj. "puščavnikom«) njihovo ime, ki je v širšem smislu hiponim termina monachós (»menih«), kar pomeni »sam «. ${ }^{59}$ Ko je abba Arsenij prosil Boga za razodetje, kako naj doseže odrešenje, bi naj

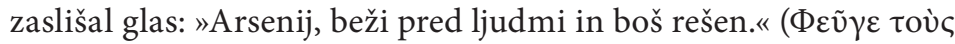

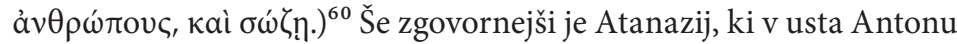
Velikemu položi ihtiološko prispodobo:

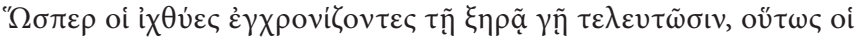

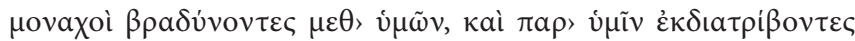

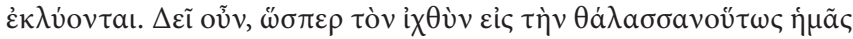

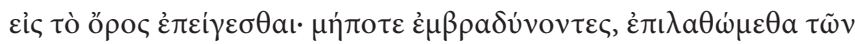
हैं $\delta$ ov. (VA 85)

Prav kakor ribe poginejo, če ostanejo na kopnem, tako se menihi razpustijo, če se mudijo pri vas in prebivajo med vami (sc. med ljudmi). Zato se moramo zdaj vrniti v goro kakor riba v morje, da ne bi zaradi pomujanja pozabili na to, kar je v notranjosti.

»Filozofijo puščave«, duhovnost, ki se je izoblikovala med prvimi puščavniki, lahko tako razumemo tudi kot filozofijo samote. Še Mark Avrelij je sicer govoril o tem, kako »silno nespametna je« vsaka prisilna fizična osama, »ko pa se lahko vsako uro umakneš v samega

Hunt, Clothed in the Body: Asceticism, the Body and the Spiritual in the Late Antique Era, 17.

56 Cf. Kirschner, »The Vocation of Holiness in Late Antiquity«, 109.

57 VA 14.

58 To konotacijo dobi s krščanstvom, v prvotnem pomenu besede gre prvenstveno le za »umik« ali celo »pobeg«, bodisi iz bitke, pravne obravnave ali pa tudi sveta in družbenih struktur na splošno; glej Guillaumont »Anachoresis«, 119a-12ob. "Anahoreti« pa niso bili edini tip menihov, ki so se pojavili v Egiptu tistega časa - cf. Hieronim Ep. 22.34.1 in Ep. 125, o različnih vrstah menihov piše Caner, Wandering, Begging Monks: Spiritual Authority and the Promotion of Monasticism in Late Antiquity, 7-12. 
sebe ${ }^{61}{ }^{61}$ a se krščanskim asketom ni zdelo dovolj asketsko živeti na domu, sredi mesta in družbe, temveč so za doseg notranje samote iskali tudi zunanjo osamitev in jo tako postavili za temeljni kriterij meniške duhovnosti.

Četudi torej že znotraj grške filozofije najdemo različne primere asketskih praks, ki so poznejšim sorodne tako strukturno kot po udejanjanju, pa osamo kot sine qua non vzpostavi šele krščanski asketizem. Eric Robertson Dodds, ki v mnogih ozirih ostaja referenčni preučevalec krščanstva in njegovih poganskih korenin v grški filozofski tradiciji, sicer opozarja na primere osamitve tudi v pred-meniški judovsko-krščanski tradiciji: ${ }^{62}$ na samotarskega Elijo, ${ }^{63}$ Filonove therapeutae in Janeza Krstnika, čigar vox clamantis in deserto ${ }^{64}$ je nedvomno prototip puščavništva. Kar zadeva antično pogansko filozofijo je poleg pitagorejcev edini znani primer "poganskega puščavnika « Sostrat, o katerem beremo pri Lukijanu iz Samosate (ok. 125-po 180), v začetku njegove biografije kiniškega filozofa Demonaksa. ${ }^{65}$ Vendar Sostrat bolj kot na asketa, ki se je umaknil v osamo, spominja na heroja, ki neustrašno spi sam pod golim nebom (tudi njegov vzdevek je »Herakles«). ${ }^{66}$ Zavračanje družbe(nosti) in željo po osami bi lahko iskali tudi pri predsokratikih - Heraklitu, čeravno ima ta zanjo bolj mizantropske razloge ${ }^{67}$ - ali pozneje pri Pironu, ki se je, po pričevanju Diogena Laertskega, "umikal iz družbe, živel v samoti in se le redko kazal domačim « ${ }^{68}$

61 Tà eis heautón 4.3.

62 Dodds, Pagan and Christian in an Age of Anxiety: Some Aspects of Religious Experience from Marcus Aurelius to Constantine, 31.

$631 \mathrm{Kr} 17,6$; cf. De laude 18.

64 Iz 40,3; Lk 3,1; Mt 3,3; Mr 1,2; Jn 1,23; Ambrož, De fuga saeculi 6.34, Hieronim Ep. 58.5.3. Cf. Canellis, »Désert et ville dans la Correspondance de saint Jérôme«, 22-48.

65 Z zornega kota poganske recepcije krščanstva je zanimivo tudi Lukijanovo delo

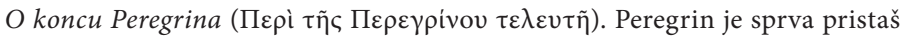
kiniške šole, ki se spreobrne v krščanstvo, pristane v ječi in se na koncu navduši za indijsko filozofijo.

66 Jamblih v Vita Pythagorae opisuje Pitagorov prihod v Kroton (VP 6.29). Tam naj bi živeli Pitagorovi privrženci, ki niso bili navdušeni le nad njegovo filozofijo, pač pa tudi nad »skupnim življenjem«, od koder tudi ime »koinobiti«

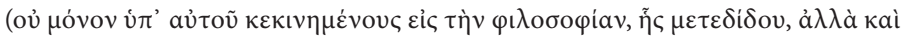

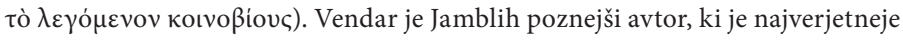
uporabil krščanski izrazni aparat za opis poganske religijske skupine in ne vice versa. Cf. Finn, Asceticism in the Graeco-Roman World, 31.

67 Diogen Laertski (9.3) razlaga, da se je zaradi sovraštva človeške vrste in neumnosti ljudi pred njimi umaknil visoko v gore in živel od zeliščnih bilk.

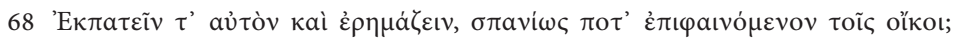
Diogen podobno opisuje tudi Pironovega učenca Filona. Ibid. 9.69. 
Toda kot pomembnejše vprašanje od tega, koliko je bilo dejanskih asketov v krščanskem smislu že v poganski antiki, se kaže pomen same asketske naravnanosti, razmišljanja in teženj po prakticiranju askeze, ki so bile vsekakor prisotne že pred nastopom krščanstva. Kot smo videli, je namreč temeljne kategorije askeze vzpostavila že poganska antika. Krščanski asketi tako niso prav zares igrali pionirske vloge - izhajali so iz duhovnega horizonta poganske áskesis. Prav ta je tvorila transcendentalno podlago za eremitski obrat $\mathrm{k}$ transcendenci: novost, $\mathrm{ki}$ pa so jo prinesli, je ta, da se je ta obrat zgodil v fizični izolaciji, sredi gorate Vzhodne egiptovske puščave. »Proces osvoboditve od sveta « je bil, kot v svoji študiji Telo in družba zapiše Peter Brown, poistoveten s preselitvijo iz "poseljene egiptovske dežele v puščavo « ${ }^{69}$

Četudi se je torej bodoči puščavnik za askezo vsekakor odločil v novem duhovnem kontekstu krščanske vere in na podlagi branja Svetega pisma, ${ }^{70}$ pa pri tem ne gre pozabiti, da je izhajal iz duhovnega miljeja, ki mu askeza nikakor ni bila tuja. Mnenja o tem, v kolikšni meri so se krščanski asketi neposredno napajali ob poganski asketski tradiciji, so deljena. Po Atanazijevem pričevanju si Anton denimo »ni maral pridobiti izobrazbe« ozi-

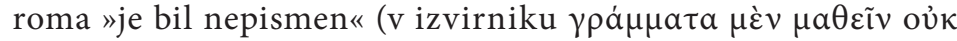

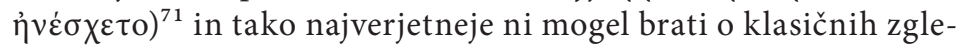
dih poganske askeze in se navdihovati ob njih. Nedvomno pa so bili krščanski asketi duhovni dediči poganskega asketizma; ta duhovna dediščina se je le malo pozneje ali sinhrono z njihovimi življenji prelila v biografije, pridige in traktate cerkvenih očetov, iz katerih asimilacija poganske filozofije v krščansko odseva še jasneje. Iz spoja teh dveh se oblikujejo temelji meniške književnosti in izročila. ${ }^{72}$ pojdi, prodaj, kar imaš, in daj ubogim in imel boš zaklad v nebesih« (Mt 19,21), kar je zanj usodnega pomena.

71 VA 1, kar je tudi ena od sprememb, ki jih prinese izvorno puščavništvo: »premik od kulture knjige h cultura Dei« - za svete može postane značilno, da se učijo le iz knjige narave, izobražujejo pa se preko srca, ne preko razuma. Brown, Telo in družba, 289. Cf. Hunt, Clothed in the Body, 16. 


\section{MENIŠTVO KOT »RESNIČNA FILOZOFIJA«}

Že zelo zgodaj so kristjani privzeli svoje pojmovanje filozofije, do katere so, zaradi njenega poganskega izvora, imeli sicer previden odnos, a so jo hitro vzeli za svojo in pozneje meništvo oklicali celo za edino pravo filozofijo. Ta postopna asimilacija, ki prehaja $\mathrm{v}$ transformacijo pomena filozofije, se pojavi že pri apologetih.

Justin Mučenec (100-165) govori o krščanstvu kot o »naši filozofiji«: grški filozofi naj bi bili deležni le dela Lógosa, medtem ko ga kristjan vidi v njegovi celoti. ${ }^{74}$ Werner Jaeger tako opozarja na sam začetek Justinovega Dialoga, kjer glavni protagonist, Jud Trifon, naleti na grškega filozofa, ki mu nemudoma po uvodnem pozdravu in ugotovitvi, da je filozof, reče: »Ali se ne nanaša vsaka misel filozofov na Boga in ali se njihova razpravljanja ne vrtijo vselej okrog enovite Oblasti (nad vsem) in previdnosti? Ali ni delo filozofije to, da raziskuje o Božanstvu? «" ${ }^{75}$

Izraz »krščanska filozofija « je prvi uporabil Janez Krizostom. ${ }^{76}$ Ta v svojih delih večkrat nagovarja k preprostosti - za ideal krščanskega življenja postavlja kmečko življenje na deželi, po hribih, čim dlje stran od mesta. Ključno razliko med krščansko in pogansko filozofijo namreč med drugim vidi prav v scenografiji: poganska filozofija se dogaja $\mathrm{v}$ mondenem okolju mest in izobražencev, kjer se njen pomen izgublja, brade (quae non faciunt philosophum) pa se daljšajo, medtem ko se v življenju kmeta sredi narave filozofija še zmeraj lahko vrši kot način življenja. ${ }^{77} \mathrm{~V}$ tem oziru je zanimivo tudi Krizostomovo delo Adversus oppugnatores vitae monasticae - didak-

73 Claudio Moreschini Justina označi za "prvega krščanskega filozofa« sploh: Claudio Moreschini, Storia della filosofia patristica, 77.

74 Dialogus 8.1; Apologia 2.13.3. O Justinovem polemiziranju glede razlik med krščanstvom in pogansko filozofijo piše Franci Zore, »The Relationship between Philosophy (Knowledge) and Religion (Faith) in St. Justin Martyr's Foundation of Christian Philosophy«, 47-57.

75 Prevod po slovenski izdaji Jaegrovega dela: Werner Jaeger, Zgodnje krščanstvo in grška paideía, 111.

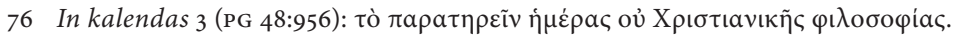
Cf. Stenger, »Where to Find Christian Philosophy? Spatiality in John Chrysostom's Counter to Greek Paideia «, 175.

77 Homilia 21 de Statuis 19.1-2 in Hom. in Job 2.2; s svetostjo angelov vzporeja menihe v In catechumenos 8.4. Obširnejši pregled zgoraj nakazanega Krizostomove pojmovanja prinaša Stenger, »Where to Find Christian Philosophy?« 17398. O Krizostomovem opisovanju duhovnika kot »svetnega asketa in nekaterih korelacijah s filozofijo piše Rylaarsdam, John Chrysostom on Divine Pedagogy: The Coherence of his Theology and Preaching, 194-227. 
tično obarvana apologija meniškega življenja. V drugi knjigi tako k temu, naj sina spodbuja k meništvu, Krizostom nagovarja poganskega očeta, v tretji pa kristjana. Za nas je relevanten predvsem nagovor poganskega očeta, saj v njem, ker nagovarja pogana, Krizostom poseže po poganskih sredstvih - meništvo utemeljuje na podlagi poganske filozofije. Kot opozarja Jean-Louis Quantin, se v drugi knjigi beseda "filozofija« pojavlja zelo pogosto in, kar je ključno, povsem samostojno, brez krščanskega konteksta. ${ }^{78}$ Lik poganskega in krščanskega očeta $\mathrm{v}$ besedilu stojita le pro forma - Krizostom je želel pokazati predvsem na to, da ima krščansko meništvo prav tako visoko, če ne še višjo vrednost kot poganska filozofija. ${ }^{79}$ Podobno kot Evherij pa tudi sam pozneje filozofijo postavi v puščavo: v mestih na-

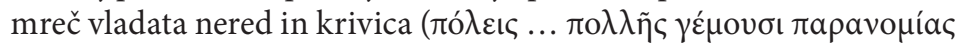

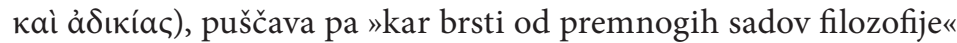

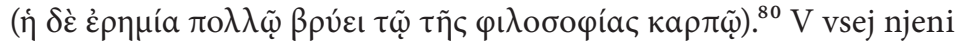
polnosti so filozofijo uresničili le »menihi, še pred njimi apostoli,

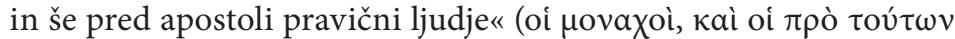

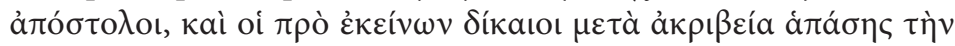

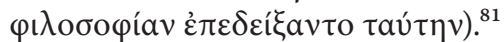

Klemen Aleksandrijski (150-215) v svojem delu Stromata na več mestih pravi podobno, ${ }^{82}$ Gregor iz Nazianza (329-39o) meništvo brez večjih zadržkov okliče za "resnično filozofijo «, ${ }^{83}$ Efrem Sirski (ok. 306-373) pa poda povsem asketsko definicijo filozofa, ko trdi, da je "resničen filozof tisti, ki se upira svojim slabim poželenjem «. ${ }^{84}$ Ne le izenačenje, pač pa celo nadvlado puščavniške molitve nad vsakršnim filozofiranjem posreduje že Vita Antonii, v kateri Atanazij opiše dva "grška filozofa», ki sta prišla k Antonu:

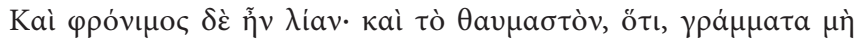

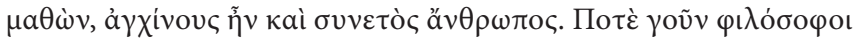

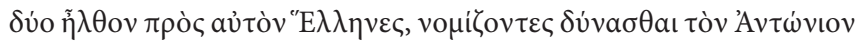

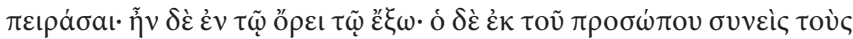

Quantin, "A propos de la traduction de philosophia dans l'Adversus oppugnatores vita monasticae de Saint Jean Chrysostome«, 191. Ibid. 196. Adversus oppugnatores vitae monasticae 1.7. Ibid. 3.19. Stromata 1.13-21. Oratio 25.2. Glej tudi Ruether, Gregory of Nazianzus: Rhetor and Philosopher, 167-74.

84 Referenca in prevod v razpravi, ki jo je spisal Kobusch, Krščanska filozofija: odkritje subjektivitete, 45. 


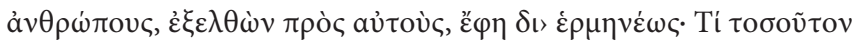

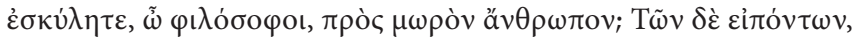

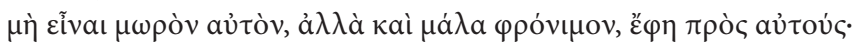

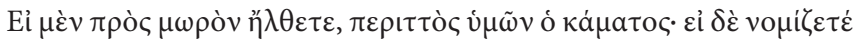

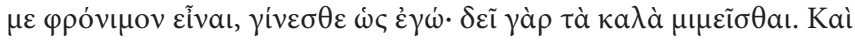

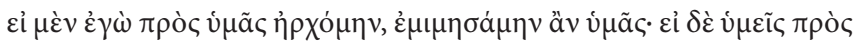

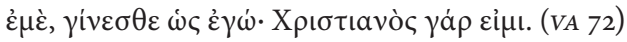

Bil je tudi silno moder. Osupljivo je, kako bistroumen in pameten človek je bil, čeprav ni bil deležen izobrazbe. Nekoč sta tako prišla k njemu dva grška filozofa, misleč, da bosta Antona lahko preizkusila; takrat je bil v zunanji gori. On pa ju je prepoznal po njuni zunanjosti, jima šel naproti in po tolmaču dejal: »Filozofa, zakaj si nakopavata toliko truda, da bi prišla do bedaka?« Ko sta odvrnila, da ni bedak, temveč zelo moder, jima je rekel: „Če sta prišla k beda$\mathrm{ku}$, je bil vajin trud prazen; če pa me imata za modrega, postanita kakor jaz. ${ }^{85}$ Kar je dobro, je treba namreč posnemati. Če bi jaz prišel $\mathrm{k}$ vama, bi vaju posnemal; ker pa sta vidva prišla $\mathrm{k}$ meni, postanita kakor jaz $z^{86}$ - in jaz sem kristjan.«

Hadot za začetnika takšnega pojmovanja filozofije postavi Filona Aleksandrijskega, ki v delu De vita contemplativa omenjeno asketsko skupnost poistoveti s »filozofi ${ }^{87}$ vse ostale zgoraj naštete avtorje pa vidi kot dediče že vzpostavljenega koncepta krščanske filozofije. ${ }^{88}$ Če je torej antična filozofija primarno pomenila način življenja - kot je pokazal prav Hadot - so bili prvi asketi in menihi najresničnejši filozofi, ki so to filozofijo privedli do najvišje točke: njihovo filozofiranje je vselej že živeto. V samoti puščavske celice usmerjajo misli k Bogu - v njej je to lažje dosegljivo, saj so prosti družbenega življenja in nemira misli, razpršenih po vsakdanjih opravkih v družbeni sistem vpetega človeka. O prav takem pomenu meništva kot "živete in izkušene filozofije " piše Jean Leclercq, ${ }^{89}$ Theo Kobusch pa skladno s Hadotom v krščanstvu vidi »dopolnitev razvoja« antične filozofije kot načina življenja. ${ }^{90}$

$85 \mathrm{Gal}_{4,12 .}$

86 Ibid.

87 Cont. 26.

88 Hadot, Philosophy as a Way of Life, 129.

89 Leclercq, »Pour l'histoire de l'expression 'philosophie chrétienne'«, 221.

90 Kobusch, Krščanska filozofija: odkritje subjektivitete, 48. 


\section{ZAKLJUČEK}

Askeza v obeh svojih dimenzijah izhaja iz filozofske utemeljitve, kot jo podaja že antična poganska filozofija. Tako »duhovne« kot »telesne vaje« koreninijo v višjem vrednotenju človekove duhovne eksistence nad telesno in se kot take porajajo kot posledica oziroma celo stranski učinek tega filozofskega stališča. Zgornja študija se ne posveča razliki, ki jo glede na duhovni horizont poganske antike $\mathrm{v}$ dojemanje askeze vpelje ontološka podlaga krščanske askeze, temveč skuša pokazati na obstoj asketskih konceptov in praks še pred krščanstvom. Kot differentia specifica krščanske askeze se kaže šele fizična osamitev - odhod krščanskih asketov $\mathrm{v}$ puščavo in posledična uvrstitev osamitve med poglavitne kriterije askeze. Prav v tem oziru so krščanski asketi nasledniki antične filozofije, na katero opozarja Hadot: najznačilnejša poteza obeh je filozofija kot modus vivendi. Antični filozofi so jo prakticirali po mestih, saj ni bilo »filozofa niti filozofije zunaj neke skupine, skupnosti «, ${ }^{91}$ krčanski asketi pa so se pred vsemi pastmi, ki jih predstavlja življenje v mestnem vrvežu, zatekli v puščavsko samoto, kjer so se, kot beremo pri Evheriju, »k študiju te najresničnejše modrosti« obračali še »toliko lepše in veličastneje«. Ta novum, ki ga v pojmovanje živete filozofije prinaša krščanstvo, pa se je razlegal daleč čez poznejša obdobja: ideal puščavniške samote se skriva tako $\mathrm{v}$ srži koncepta contemptus mundi kot omahovanja med vita activa in vita contemplativa. ${ }^{92}$ Brez obravnavane najvidnejše razlike, ki jo $\mathrm{v}$ asketski diskurz vnaša krščanstvo, se Bernard iz Clunya ne bi obračal k tej temi, veliki navdihovalci nad pogansko antiko pa ne bi pisali del, kot je Petrarkova razprava $D e$ vita solitaria. Z razmahom krščanske askeze je puščava za filozofijo postala najprimernejši dejanski, puščavska samota pa literarni topos. 


\section{BIBLIOGRAFIJA}

Viri

Apophthegmata patrum. PG 65.72-440.

—_. Hrovat, Jasna. Izreki svetih starcev. Celje: Mohorjeva družba, 2002. Athanasius. Vita Antonii. V: Athanase d'Alexandrie, Vie d'Antoine, ur. in prev. Gerard J. M. Bartelink, 123-377. Sources chrétiennes 400. Pariz: Les Éditions du Cerf, 1994.

Cicero. De senectute. V: Cicero: On Old Age; On Friendship; On Divination, ur. W. A. Falconer, 9-99. Loeb Classical Library 154. Cambridge, MA: Harvard University Press, 1923.

__. Pogovori o starosti - Cato maior de senectute. Prevedla Vida Pust Škrgulja. Ljubljana: Inštitut Antona Trstnjaka, 2015.

Diogenes Laertius. Diogenis Laertii vitae philosophorum. Ur. Miroslav Marcovich. Teubneriana 1316. Stuttgart-Leipzig: Teubner, 1999.

___ Življenja in misli znamenitih filozofov. Prevedli Živa Borak et al. Ljubljana: Beletrina, 2015.

Euagrius Ponticus. Traité pratique ou Le Moine. Ur. Antoine in Claire Guillaumont. Sources Chrétiennes 171. Pariz: Cerf, 1971.

__- Spisi in pisma. Prevedla Gorazd Kocijančič in Alen Širca. Ljubljana: KUD Logos, 2015.

Hieronymus. De viris illustribus. Ur. A Ceresa Gastaldo. Firence: Nardini Editore, 1988.

Iamblichus. De vita Pythagorica. V: Iamblichi de vita Pythagorica liber 1-147. Ur. L. Deubner in U. Klein. Stuttgart: Teubner, 1975.

Ioannes Chrysostomus. In kalendas. PG 48:956

—_. Adversus oppugnatores eorum qui vitam monasticam inducunt oppugnatores vitae. PG 47:319-86

Marcus Aurelius. Dnevnik cesarja Marka Avrelija. Prevod Anton Sovrè. Ljubljana: Slovenska matica, 2006.

Philo. Philonis Alexandrini opera quae supersunt. Ur. Leopold Cohn. Berlin: Reimer, 1902.

Plato. Platonis opera. Ur. John Burnet. Oxford: Clarendon Press, 1900-1907.

—_ Z Zbrana dela. Prevod Gorazd Kocijančič. Celje: Celjska Mohorjeva družba, 2006.

Plotinus. Zbrani spisi. Prevedla Sonja Weiss. Ljubljana: Slovenska matica, 2016.

Porphyrius. Ad Marcellam. Ur. W. Pötscher. Griechischer Text herausgegeben, übersetzt, eingeleitet und erklärt. Leiden: Brill, 1969.

__ De abstinentia. V: Porphyrii philosophi Platonici opuscula selecta, ur. A. Nauck. Leipzig: Teubner, 1886, ponatis 1963. 
- Vita Plotini. V: Plotini opera. Ur. P. Henry in H.-R. Schwyzer, zv. 1, 1-41. Leiden: Brill, 1951.

___ Zbrani spisi. Prevod Sonja Weiss. Ljubljana: Slovenska matica, 2016.

\section{Literatura}

Belting, Hans. "St. Jerome in Venice: Giovanni Bellini and the Dream of Solitary Life«. I Tatti Studies in the Italian Renaissance 17, št. 1 (2014): 5-33.

Bieler, Ludwig. Theios aner: Das Bild des "göttlichen Menschen" in Spätantike und Frühchristentum. Dunaj: O. Höfels, 1935.

Božič, Blaž. „Dionizova smrt in etični dualizem: nekaj misli o Olimpiodorjevi antropogoniji in neoplatonističnih opisih manihejskega kozmosa«. Keria: Studia Latina et Graeca 21, št. 1 (2019): 31-44.

Brown, Peter. Telo in družba: Spolno odrekanje v zgodnjem krščanstvu. Ljubljana: Studia humanitatis, 2007.

___ . - The Rise and Function of the Holy Man in Late Antiquity«. Journal of Roman Studies 61 (1971): 80-101.

Bynum, Caroline Walker. Holy Feast and Holy Fast. Berkley: University of California Press, 1988.

Cameron, Averil. »Ascetic Closure and the End of Antiquity«. V: Asceticism, ur. Vincent L. Wimbush in Richard Valantasis, 147-61. Oxford: Oxford University Press, 1998.

Clark, Elizabeth A. Reading Renunciation: Asceticism and Scripture in Early Christianity. Princeton: Princeton University Press, 1999.

Canellis, Aline. »Désert et ville dans la Correspondance de saint Jérôme«. Vigiliae Christianae 67 (2013): 22-48.

Diem, Albrecht. »The Limitations of Asceticism«. Medieval Worlds: Comparative \& Interdisciplinary Studies 9 (2019): 112-39.

Dillon, John M. »Rejecting the Body, Refining the Body: Some Remarks on the Development of Platonist Asceticism«. V: Asceticism, ur. Vincent L. Wimbush in Richard Valantasis, 80-87. Oxford: Oxford University Press, 1998.

Dodds, E. R. Pagan and Christian in an Age of Anxiety: Some Aspects of Religious Experience from Marcus Aurelius to Constantine. Cambridge: Cambridge University Press, 1968.

Domański, Juliusz. "Remarks on the Medieval and Renaissance 'Contempt of the World' and 'Human Misery' (Lotario - Poggio Bracciolini Erasmus of Rotterdam)«. Odrodzenie i Reformacja w Polsce 36 (1992): 5-52.

Flachbartová, Lívia. »The Care of the Self and Diogenes’ Ascetic Practices«. V: Care of the Self: Ancient Problematizations of Life and Contemporary Thought, 50-96. Leiden: Bril-Rodopi, 2017. 
Festugière, André-Jean. Contemplation et vie contemplative selon Platon. Pariz: Librarie Philosophique J. Vrin, 1967.

Finn, Richard. Asceticism in the Graeco-Roman World. Cambridge: Cambridge University Press, 2009.

Folger Caner, Daniel. Wandering, Begging Monks: Spiritual Authority and the Promotion of Monasticism in Late Antiquity. Berkeley: University of California Press, 2002.

Foucault, Michel. Zgodovina seksualnosti. Ljubljana: ŠKUC, 2010.

Frank, Georgia. The Memory of the Eyes: Pilgrims to Living Saints in Christian Late Antiquity. Berkeley: University of California Press, 2000.

Goehring, James E. »The Origins of Monasticism«. V: Eusebius, Christianity and Judaism, ur. H. W. Attridge in C. Hato, 235-55. Leiden: Brill, 1992.

Gould, Graham. The Desert Fathers on Monastic Community. Oxford: Clarendon Press, 1993.

Graiver, Inbar. Asceticism of the Mind: Forms of Attention and Self-Transformation in Late Antique Monasticism. Toronto: Pontifical Institute of Mediaeval Studies, 2018.

Hadot, Pierre. Philosophy as a Way of Life: Spiritual Exercises from Socrates to Foucault. Oxford: Blackwell Publishers, 1995.

___ La citadelle intérieure: introduction aux Pensées de Marc Aurèle. Pariz: Fayard, 1992.

. Kaj je antična filozofija? Ljubljana: Krtina, 2009.

Harmless, William. Desert Christians: An Introduction to the Literature of Early Monasticism. New York: Oxford University Press, 2004.

Harpham, Geoffrey. The Ascetic Imperative in Culture and Criticism. Chicago: University of Chicago Press, 1987.

Hunt, Hannah. Clothed in the Body: Asceticism, the Body and the Spiritual in the Late Antique Era. Farnham: Ashgate Publishing, 2012.

Ivánka, Endre von. Plato Christianus: Übernahme und Umgestaltung des Platonismus durch die Väter. Einsiedeln: Johannes Verlag, 1964.

Jaeger, Werner. Zgodnje krščanstvo in grška paideía. Ljubljana: KuD Logos, 2014.

Judge, Edwin A. »The Earliest Use of Monachos for 'Monk'«. Jahrbuch für Antike und Christentum 20 (1977): 72-89.

Kingsley, Peter. Ancient Philosophy, Mystery, and Magic: Empedocles and Pythagorean Tradition. Oxford: Oxford University Press, 1996.

Kirschner, Robert. »The Vocation of Holiness in Late Antiquity«. Vigiliae Christianae 38, št. 2 (1984): 105-24.

Kobusch, Theo. Krščanska filozofija: Odkritje subjektivitete. Ljubljana: KUD Logos, 2019.

Leclercq, Jean. »Pour l'histoire de l'expression 'philosophie chrétienne'«. Mélanges de Science Religieuse 9 (1952): 221-26. 
Louth, Andrew. The Origins of the Christian Mystical Tradition: From Plato to Denys. Oxford: Oxford University Press, 2007.

Moreschini, Claudio. Storia della filosofia patristica. Brescia: Morcelliana, 2004.

Movrin, David. »Izviri onkraj izvirov: Odnos med pogansko in krščansko biografijo v pozni antiki«. V: Izviri meništva, 243-414. Celje: Celjska Mohorjeva družba, 2011.

Philo of Alexandria. The Contemplative Life, The Giants, and Selections. Prevod David Winston. New York: Paulist Press, 1981.

Pricoco, Salvatore. Elogio del eremo: Introduzione, testo, traduzione e commento. Bologna: ED, 2014.

__L L'isola dei santi: Il cenobio di Lerino e le origini del monachesimo gallico. Rim: Edizioni dell'Ateneo \& Bizzarri, 1978.

Quantin, Jean-Louis. "A propos de la traduction de philosophia dans l'Adversus oppugnatores vita monasticae de Saint Jean Chrysostome«. Revue des Sciences religieuses 61 (1987): 187-97.

Rubenson, Samuel. „Christian Asceticism and the Emergence of the Monastic Tradition«. V: Asceticism, ur. Vincent L. Wimbush in Richard Valantasis, 49-57. Oxford University Press, 1998.

Ruether, Rosemary Radford. Gregory of Nazianzus: Rhetor and Philosopher. Oxford: Clarendon Press, 1969.

Rylaarsdam, David. John Chrysostom on Divine Pedagogy: The Coherence of his Theology and Preaching. New York-Oxford: Oxford University Press, 2014.

Stenger, Jan R. »Where to Find Christian Philosophy? Spatiality in John Chrysostom's Counter to Greek Paideia«. Journal of Early Christian Studies 24, št. 2 (2016): 173-98.

Swaine, Joseph Ward. The Hellenic Origins of Christian Asceticism. New York: Columbia University, 1916.

Ware, Kallistos. »The Way of the Ascetics: Negative or Affirmative?« V: Ascetics, ur. Vincent L. Wimbush in Richard Valantasis, 3-15. Oxford University Press, 1998.

Whittaker, Helene. »The Purpose of Porphyry's Letter to Marcella«. Symbolae Osloenses: Norwegian Journal of Greek and Latin Studies 76, št. 1 (2001): 150-168.

Wolfson, Harry Austryn. Philo: Foundations of Religious Philosophy in Judaism, Christianity, and Islam. Massachusetts: Harvard University Press, 1947.

Zore, Franci. »The Relationship between Philosophy (Knowledge) and Religion (Faith) in St. Justin Martyr's Foundation of Christian Philosophy«. V: Antiquity and Christianity: Conflict or Conciliation? Proceedings from the International Symposium, ur. Vid Snoj, 47-57. Ljubljana: KUD Logos, 2007. 


\section{IZVLEČEK}

Izhajajoč iz označitve puščave kot najprimernejšega kraja za posvečanje filozofiji, ki jo v Hvalnici puščave (De laude eremi) poda Evherij Lyonski, članek raziskuje krščansko recepcijo antične poganske filozofije, zlasti z ozirom na askezo. V skladu s Hadotovim pojmovanjem antične filozofije kot načina življenja se $\mathrm{v}$ prvi polovici osredotoča na koncept in prakso askeze, ki se je izražala v obliki »duhovnih vaj« ali telesne vzdržnosti. Ob ugotovitvi, da sta obe dimenziji askeze obstajali že v klasični grški filozofiji, se kot differentia specifica krščanske askeze izkaže fizična osamitev - odhod krščanskih asketov $\mathrm{v}$ puščavo. Članek tako v drugi polovici izpostavi poistovetenje filozofije z meništvom in sledi njeni asimilaciji v kontekst krščanske askeze, ki osamitev umesti med temeljne kriterije »filozofije«.

KLJUČNE BESEDE: askeza, puščavništvo, antična poganska filozofija, Evherij Lyonski, meništvo 
EREMITA ALTER PHILOSOPHUS: UNDERSTANDING ASCESIS IN PAGAN AND CHRISTIAN PHILOSOPHY

\section{ABSTRACT}

Starting from the designation of the desert as the most suitable place for devotion to philosophy, as alluded to in the Praise of the Desert (De laude eremi) by Eucherius of Lyon, the article explores the Christian reception of ancient pagan philosophy concerning asceticism. In line with Hadot's conception of ancient philosophy as a way of life, the article focuses on the concept and practice of asceticism, expressed in the form of "spiritual exercises" or physical endurance. While both dimensions of asceticism already existed in classical Greek philosophy, physical isolation - the departure of Christian ascetics into the desert - proves to be the differentia specifica of Christian asceticism. The article highlights the identification of philosophy with monasticism and follows its assimilation into the context of Christian asceticism, which places isolation among the fundamental criteria of "philosophy."

KEYWORDS: asceticism, eremitism, ancient/classical/Greek philosophy, Eucherius of Lyon, monasticism 